\title{
Self-Control Kleptomania Sufferers
}

\author{
M. Fadli Nugraha \\ Lecturer at Universitas Medan Area North Sumatra, Indonesia \\ fadlinugraha@staff.uma.ac.id
}

\begin{abstract}
This study aims to determine empirically self-control in patients with Kleptomania in Medan, North Sumatra. The method in this study uses qualitative. The sampling technique is based on the theoretical operational construct and in this study the sample used was only one kleptomania sufferer with two informants who knew best about him. The research instrument used was through observation, interviews and projective techniques. Data collection aids use interview guidelines, recording devices, stationery and TAT (Thematic Apperception Test). Data analysis techniques using the analysis of Miles and Huberman models. The results in the study showed that rivalry sibling and lack of communication triggered the emergence of Kleptomania disorders. The typical thought control is that it cannot control its thinking. Likewise, emotional control and momentary impulses that occur only for momentary satisfaction and enjoy the process of owning other people's belongings. Performance regulation controls are also low. The desire to repent is smaller than the desire to do Kleptomania. The TAT results show in line with the fact that perpetrators continue to be motivated to do so because of the environment and difficult impulses in the opponent.
\end{abstract}

Keywords: self, control, kleptomania, TAT

\section{Introduction}

Theft is a criminal act in the form of taking other people's belongings without the owner knowing. The rise of theft today causes security and comfort in the community. Very often these acts of theft begin with the difficulty of finding adequate employment. Not only that, theft occurred not only in the economic background but could also be due to the influence of drugs which is currently the first destroyer of the Indonesian nation's generation. "As clever as a squirrel, jumping will surely fall as well", this proverb is precisely attributed to the theft that often occurs in the community before getting punishment from the government. Not infrequently the perpetrators of theft feel the "mass tantrums" first.

Not all theft is the same, only want the sale value or the value of the stolen goods. Theft is considered very taboo and, is a shortcut to get the property of others without having to work hard. In contrast to theft which is not driven by economic factors or 
because it is influenced by drugs, theft is driven by a sense of wanting to have without being able to control their desires and these actions occur repeatedly without the offender being able to withstand the desire. Often the perpetrator does not recognize his actions, the desire to have the goods of others is often of no value to the perpetrator and often has no economic value.

In accordance with what Kartono stated (Prabowo \& Karyono, 2014) that acts of crime can be done consciously, that is thought, planned and directed at one particular purpose consciously right. But it can also be done semi-consciously, for example driven by great impulses, wracked by very strong coercive impulses (compulsions), and by obsessions.

This theft is called Kleptomania. This theft is carried out semi-consciously, for example driven by great impulses, wracked by very strong coercive impulses (compulsions). In accordance with what was stated in the Diagnostic Statistical Manual of Mental Disorder IV (1995) that basically the characteristics of Kleptomania are repeatedly failed to resist the urge to steal items even though they are not needed for personal use or for financial value they.

Clptomania sufferers with a lack of self-control will experience difficulty controlling their impulses and directing positive forms of behavior. As Feist's opinion (Praptiani, 2013) states self-control is the ability of individuals to control emotions, impulses from within themselves to regulate physical processes, psychological, behavior in compiling, guiding, regulating and directing positive forms of behavior in order to be accepted in social environment.

In DSM IV (1995) it is said that sufferers of Kleptomania have the characteristics of repeatedly failing to resist the urge to steal goods even if the items are not needed for personal use or for their financial value. Then the individual experiences an increased sense of tension before stealing and feels pleasure, satisfaction, or relief when committing theft. Stealing is not done to express anger or revenge, it is not done in a state of delusion or hallucination. Usually noted as an anti social disorder.

Seeing the above description, it can be seen that Kleptomania does not have high selfcontrol so that often Kleptomania is less accepted and cared for by its environment which is then ignored and ignored by the community. Furthermore, this archipelago community used to still hold a socialist culture and still respect deliberation in the midst of the community and did not judge itself if there was a mistake in moral and cultural values. But that matter can no longer be discussed in the archipelago today, where the orientation of the community has tended to be materialist. So the perpetrators of theft often become "months" residents, without having to find out in advance, what causes it can happen to anticipate so as not to get the wrong perception. 
Of course stealing will become a habit when people do not pay attention and ignore kleptomania, which themselves find it difficult to control their impulses which can at any time "explode". Self-control in Kleptomania is very necessary, in order to be able to change, regulate and direct the forms of behavior that can lead to positive consequences, so as to produce conformity to the environment

\subsection{Significance of the study}

The results of this study are expected to contribute to the theory and be able to add to psychological knowledge and in particular to enrich theories in the field of clinical psychology related to self-control and Kleptomania. And hopefully the public can find out more about the rampant cases of theft that are happening now, so as not to judge first before proving the theft clearly from the background of the thief, whether the perpetrators suffer from Kleptomania or whether it is due to economic or drug factors. theft is not only motivated by the economic difficulties of the offender but there is theft based on lack of self-control due to compulsion interference and a sense of satisfaction when taking other people's goods that are not useful for the culprit and are of no economic value.

\subsection{Scope and Limitation of the study}

This study examines how Kleptomania can occur as well as what are the factors that influence it.

\subsection{Setting of the study}

The study was conducted in Medan City, North Sumatra Province, but regarding the place specifications could not be described because the location was wherever the respondents wanted it. This is to make interviews and observations more comfortable and open to researchers.

\section{Research Design And Methodology}

In general, the research method used is qualitative research methods. This research was conducted in Medan, North Sumatra. Patton (1990) says that the difference between qualitative and quantitative research is very evident in the sampling event. Here are some procedures for determining the source of data as proposed by Patton (1990) which basically sometimes cannot be distinguished very firmly from one another, therefore the sampling technique is done by sampling techniques based on theory or operational construct, which is then obtained samples one Kleptomania sufferer and two informants. 


\subsection{Respondents of the study}

In this study the number of respondents planned was one (1) person. The number of respondents is intended to lead to in-depth understanding. To explore the characteristics of the respondents, the ones who will become the informants of the researchers are people who have a close relationship with the respondent, who know the respondent well, such as: the respondent's biological parents, lovers (respondents 'wives), and respondents' friends.

\subsection{Research Instrument}

The research instrument used was through observation, interviews and projective techniques. Data collection aids use interview guidelines, recording devices, stationery and TAT (Thematic Apperception Test). Data analysis techniques using the analysis of Miles and Huberman models

\subsection{Data Gathering Procedure}

In this study the authors used data collection techniques are interview, observation and projective techniques. In this case the researcher only uses 10 cards, and gives 6 minutes from the researcher in each card, so it takes 1 hour to complete all cards. Projection is a form of perception that contains distortions that occur in the subconscious. Another instance of apperception is externalization. In TAT cards, individuals do not only project their inner world but also externalize and apperception (Rahmi, 2014).

\subsection{Statistical Analysis}

In maintaining the diversity and validity of the research, the researcher uses data triangulation, researcher triangulation, theory triangulation and method triangulation. Data triangulation is done by collecting data from at least 3 sources, namely through respondent 1 and informant 2. Research triangulation is expected that some researchers will evaluate this research, in this case the researcher with the two supervisors, namely Ummu Khuzaimah S.Psi, M. Psi and Laili Alfita S.Psi, MM, M.Psi.

\section{Findings And Conclusions}

As for this study, respondents had one Kleptomania sufferer with the following data: 
Table 1. Research respondents.

\begin{tabular}{|l|l|}
\hline Name/ initial & $\mathrm{R}$ \\
\hline Sex & Male \\
\hline Religion & Islam \\
\hline Status & College student \\
\hline
\end{tabular}

The following are research informant data.

Table 2. Research informants.

\begin{tabular}{|l|l|l|}
\hline $\begin{array}{l}\text { Personal } \\
\text { identity }\end{array}$ & Informan I & Informan II \\
\hline $\begin{array}{l}\text { Name / } \\
\text { Initial }\end{array}$ & $\mathrm{K}$ & $\mathrm{A}$ \\
\hline Gender & Male & Male \\
\hline Religion & Islam & Islam \\
\hline Work & $\begin{array}{l}\text { College } \\
\text { student }\end{array}$ & $\begin{array}{l}\text { Employees (now), } \\
\text { Honor teacher } \\
\text { (formerly) }\end{array}$ \\
\hline $\begin{array}{l}\text { Relationship } \\
\text { with } \\
\text { Respondents }\end{array}$ & $\begin{array}{l}\text { R friends in } \\
\text { middle and } \\
\text { high school }\end{array}$ & $\begin{array}{l}\text { The room guardian in } \\
\text { PR }\end{array}$ \\
\hline
\end{tabular}

$\mathrm{R}$ is the only child of his family, but his parents raised a son from a distant relative to become a foster child in his home. $\mathrm{R}$ and his parents live in a housing complex in the Polonia area of Medan. R's father and mother have a job that cannot be abandoned, even though on holiday R's parents have a fairly solid activity, because mother works as a businessman and father works in an office that demands both of them to work hard all the time. R's relationship with her parents is lack of communication, due to the dense work and home environment that is less sociable and less supportive for $\mathrm{R}$ at home.

$\mathrm{R}$ is currently studying at one of the universities in the city of Medan, and adoptive brother $\mathrm{R}$ has graduated with a major in law from a university in Singapore. The relationship between $\mathrm{R}$ and his adoptive brother is less harmonious, because the age is quite far and the treatment from parents who according to $\mathrm{R}$ is not fair, thus making communication between $\mathrm{R}$ and his brother less good.

$\mathrm{R}$ is a respondent who has indications of Kleptomania from a small age, so the habit is embedded deep in the subconscious of the respondent and is still 
repeated up to now but this idea was very unwanted by the respondent. Respondents claimed to want to recover and did not want to repeat it again.

Table 3. Research schedule

\begin{tabular}{|l|l|l|l|l|}
\hline No. & Day/date & Time & Place & Activity \\
\hline 1. & Sunday, 19 April & $15.00-16.00$ & $\begin{array}{l}\text { Friend's } \\
\text { rent }\end{array}$ & $\begin{array}{l}\text { - interview 1 } \\
- \text { observation 1 }\end{array}$ \\
\hline 2. & Sunday, 19 April & $17.00-18.00$ & AH & - observation 2 \\
\hline 3. & Monday, 20 April & $20.00-22.00$ & Cafe M & $\begin{array}{l}\text { - interview 2 } \\
\text { - observation 3 }\end{array}$ \\
\hline 4. & Wed, 29 April & $20.00-22.00$ & Cafe A & - observation 3 \\
\hline 5. & Wed, 6 mei & $19.00-20.00$ & $\begin{array}{l}\text { Center } \\
\text { relawan }\end{array}$ & - observation 4 \\
\hline
\end{tabular}

This section will explain the data obtained from respondents related to the problem under study and related to the theory used in this study.

The cause of the emergence of indications of Kleptomania in $\mathrm{R}$ is due to the existence of sibling rivalry which arises in the brotherhood between $\mathrm{R}$ and his adopted brother and they live in one house. That behavior appears preceded by R's jealousy towards different games between $\mathrm{R}$ and his adoptive brother and coupled with $\mathrm{R}$ is always refused to play together and may not borrow his adoptive brother's game. $\mathrm{R}$ is jealous of his big brother because his father at that time did not really pay attention to the will of $\mathrm{R}$ who really wanted his brother's game, thus making $\mathrm{R}$ choose to take his brother's goods without being known by the owner. This incident keeps happening and repeating. So that makes $\mathrm{R}$ become accustomed to these actions. This habit makes $\mathrm{R}$ feel satisfied when stealing and becomes a stress drug without being realized by $\mathrm{R}$.

This fact proves that this is the cause of the emergence of psychological disorders that exist in $\mathrm{R}$, in this case kleptomania. In accordance with what Goldman said (Pobocha, 2012) A 35 year old woman started to steal when she was 20 years old. The theft brings relief and guilt. He may not seek treatment for himself but suffer, reoccupy, and self-destruct. She may have a background in sexual dysfunction or sexual preoccupation and may be unhappy in a marriage that is not supported emotionally by her husband. He has been unstable and has been feeling dysphoria for years and may have a personality disorder. He might have uncertainty. Childhood is full of stress and may be shunned.

$\mathrm{R}$ is unable to control his thinking and cannot focus his mind on positive things and in accordance with the values of society. In his mind $\mathrm{R}$ is always filled with the urge to take other people's belongings that he cannot prevent. 
In emotional control $\mathrm{R}$ cannot hold back and stem the feeling of wanting to own the goods that he likes and those items that are not his right. $\mathrm{R}$ always fails to say no, when the situation demands to say no, $\mathrm{R}$ always fails to control his emotions, which sometimes increase sharply before committing theft, this can be seen from body movements that are uncomfortable and always restless.

Momentary impulse control is the hallmark of $\mathrm{R}$ which he cannot just press and remove. Taking other people's things without being planned in advance is often done by $\mathrm{R}$ and he always follows the sudden urge. This is consistent with the statement of Ronald and Girish (2003) Kleptomania, like other impulse control disorders, there are many kinds of impulsivity. Stealing can be done suddenly, without any prior thought or consideration of the possibility of being caught.

Low performance regulations often occur on R. There are many instances where the obligation is ignored for the sake of the pleasure of stealing, which actually also does not want the item. This has happened several times and researchers become victims of the lack of performance regulation control that is on $\mathrm{R}$. At the first interview $\mathrm{R}$ took the pin belonging to the researcher attached to the bag. This incident had already been recorded by a camera that the researchers had installed in the room. And then in the second interview in cafe $\mathrm{M}, \mathrm{R}$ was seen the camera taking white plates that had been used as a place to eat toast between researchers and $\mathrm{R}$. This can be a reference that the control regulation of $\mathrm{R}$ performance is indeed low.

Bad habits continue to repeat day after day regardless of where, and whose. This makes it difficult for $\mathrm{R}$ to get rid of his bad habits and $\mathrm{R}$ hopes that the public must understand $\mathrm{R}$ 's condition even though $\mathrm{R}$ is wrong in social perception. $\mathrm{R}$ has the intention to stop his bad habits and this was indeed conveyed several times in interview opportunities for researchers. However, it is still difficult for $\mathrm{R}$ to get rid of his bad habits due to lack of support from various parties. In accordance with what Ghufron \& Risnawati (2010) stated in outline the factors that influence self control consist of internal and external factors. The internal factors in question are factors related to within themselves including age, gender, and control of his own emotions. While external factors that influence self-control include the surrounding environment, both the family environment, peers and the environment in which he interacts socially (Ghufron \& Risnawati, 2010)

The results of these actions do not mean always smooth. Of course bad habits $\mathrm{R}$ have a negative impact on themselves. It has been recorded that $\mathrm{R}$ has moved schools twice with the same case, namely stealing belongings from friends. Not only his friend's, his teacher's also did not escape the desire to have an R who was already trained from elementary school. Some he threw away and some he 
kept in the cupboard as happened in PR, where at that time R was still sitting on a bench in Tsanawiyah or junior high school.

As William Cupchik states, he believes that the roots of Kleptomania lie in personal history. From his experience in treating theft he said, "In many cases, people experience long-standing traumatic events, most often related to losses". He described "a fine woman's activity" who was arrested for stealing 3 dresses from a Fashion Shop and then the police herded the offender to his wardrobe with 200 dresses with price tags on them. His mother was a tailor who became ill and poor and had to sell her own dress for food or money (Chee, 2010).

The impact of Kleptomania experienced by $\mathrm{R}$ is clearly seen that $\mathrm{R}$ has been expelled from school twice and $\mathrm{R}$ has absolutely no close friends either during school or after college, because R's actions are not in accordance with existing social values. And $\mathrm{R}$ also always feels restless because of the pressures that are in his mind, so that not infrequently $\mathrm{R}$ feels the stress which then takes other people's things that he likes to be a solution to reduce the stress.

In the projective technique that uses the TAT card also raises the same indication, that the self control possessed by $\mathrm{R}$ is very low, it can be seen from the unconscious impulse structure of $\mathrm{R}$ who has jealousy that is already displayed on the first card, frustrated under the shadow of the adoptive brother, want to have and have, want to be praised seen on cards 1,2, 4, 9 and 10. Then want to be considered very visible on card no. 6 and 7. Taking without permission, the need for aloof autonomy, protection, negative self image which can be seen on card no. 2, 3 and 5. feel guilty, introverted, want to control can be seen on each card.

Likewise with R's view of the environment he has in mind. The results of the cards that $\mathrm{R}$ has written assume that the environment does not need it, dumps it, feels uncomfortable, feels guilty and this is almost visible on every card. Low thinking control is also seen in the results of all cards. Like not wanting to get rid of bad habits, by not believing and closing yourself in the environment.

Relationships with others are also not far from the not better side, and also very typical of each card, the results show that rivalry sibling appears on the first card, full of competition and then incarnates into a bad habit inherent in $\mathrm{R}$ called kleptomania. Then always opposing parents passively can be seen on cards 6 and 7, this shows the low emotional control that is on R.

The result of the TAT card conflict that occurred on R is that he is increasingly losing consciousness and prefers to follow his passions or wishes. $\mathrm{R}$ has a low ego and causes the id to rise without appearing a significant super ego on each card. Conflicts also occur between wanting to control or be controlled, wanting 
to control or be controlled, and R also having conflicts wanting to be free or confined.

The nature of anxiety that results from the TAT card is more likely to lose love and helplessness so that it creates defiance against conflicts with introjection and suppression (refression) and sometimes it doesn't do anything or just ignore it. The super ego in R plays a less role and tends to be fragile. But sometimes the super ego appears to dominate so high anxiety arises. And the ego is often inadequate or in this case lacking in function because the id is taking over R.

\section{Conclusion}

Based on the results of the study, it can be concluded that rivalry sibling and lack of communication are triggering the emergence of Kleptomania disorders. The typical thought control is that it cannot control its thinking. Likewise, emotional control and momentary impulses that occur only for momentary satisfaction and enjoy the process of owning other people's belongings. Performance regulation controls are also low. The desire to repent is smaller than the desire to do Kleptomania. The TAT results show in line with the fact that perpetrators continue to be motivated to do so because of the environment and difficult impulses in the opponent.

\section{Recemendation}

First For respondents. $\mathrm{R}$ is expected to be able to open up to the right place such as to a psychologist so that the handling is also appropriate. $\mathrm{R}$ is expected to follow the advice of psychologists who have handled many cases in the clinical field, especially Kleptomania. $\mathrm{R}$ is expected to be able to find more friends so that he can share the personality problems he has.

Second, For families. It is important for families to be able to spend even a little time to interact for children, so that children feel listened to what they want. It is important for parents to give the same gift to two children of different ages, so as not to cause disputes between the two children. It is important for the older siblings to share together with the younger siblings so as not to create a dispute between the two.

Last is for further research. The next researcher is expected to be able to use quantitative research methods in order to clearly summarize how Kleptomania.

It is hoped that further researchers will use two variables to be able to see distant Kleptomania disorders. Future studies are expected to be able to sharpen more deeply and explore thoroughly about Kleptomania, especially for the category of obsession obsession. 


\section{References}

APA. (1995). DSM IV. Diagnostic and Statistical Manual of Mental Disorder. Fourth Edition. Washington DC.

Chee K.T. 2010. Making Sense of Kleptomania: Clinical Considerations. Jurnal Proceedings of Singapore Healthcare. Volume 19. Number 4.

Fajrina \& Kurniawan. (2013). Kesejahteraan relegius dan kontrol diri pada mahasiswa: studi pendahuluan. Jurnal Psikologi indonesia Vol. 10 No.1 Juli.

Gufron, M.N, \& Risnawati R. (2010) Teori-Teori Psikologi, Jogjakarta: Ar-Ruzz Media.

Ronald A.F \& Girish N.P. (2003). KLEPTOMANIA: A Brief Intellectual History. The Romance of marketing history: Charm.

Pobocha J., (2012). Impulse-Control Disorders In Forensic Psychiatry. Gauta : Journal Sveikatos Mokslai, ISSN 1392-6373. Volume 22, No. 2.

Patton, M. Q. (1990). Qualitative Evaluation and Research Methods. Newbury Park:Sage Psikologi Sosial Vol.1, No.32-47

Prabowo \& Karyono (2014). Gambaran Psikologis individu dengan kecenderungan kleptomania. Jurnal Psikologi Undip Vol.13 No.2 Oktober.

Praptiani (2013). Pengaruh kontrol diri terhadap agresivitas remaja dalam menghadapi konflik sebaya dan pemaknaan gender. Jurnal Sains dan Praktik Psikologi. Vol. 1 No. 1, Januari.

Suryantoro T. (2014). Tinjauan Yuridis Tentang Pemida naan Terhadap Anak Kleptomania.Yogyakarta: Fakultas Hukum Universitas Atma Jaya. 